\title{
MALAWI2020
}

\section{Vulnerability and Risk Assessment in the tea industry}

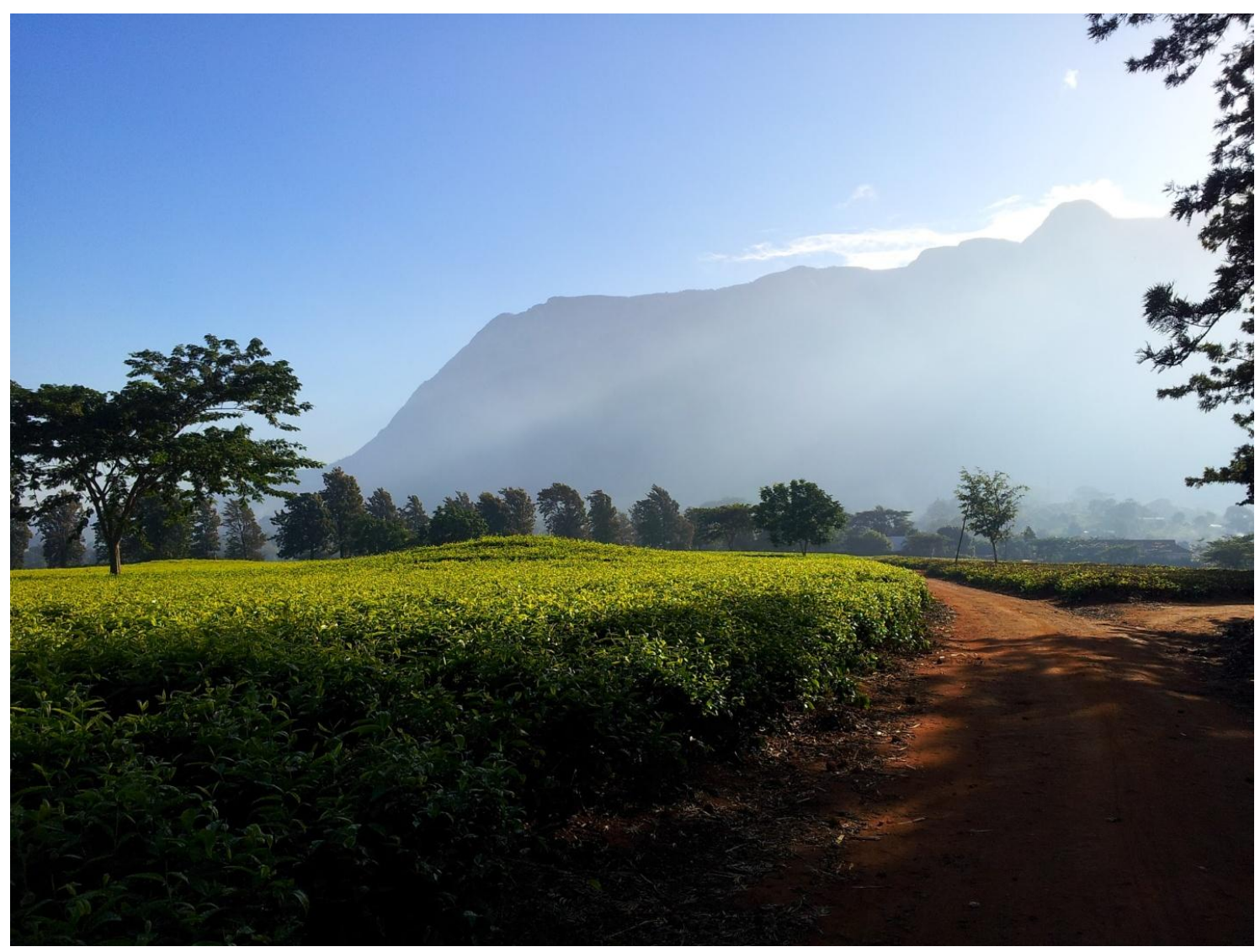

A tea plantation in Malawi. Photo: Wolfgang Weinmann/Oxfam

In June 2016, Oxfam conducted a Vulnerability and Risk Assessment (VRA) exercise in Mulanje, Southern Malawi, in the context of the Malawi2020 Tea Revitalization Programme (Malawi2020). This programme aims to achieve a competitive, profitable tea industry that can provide living wages and incomes for its workers by 2020 . The VRA sought to address the key hazards and issues affecting people and stakeholders in the tea-growing landscape of Southern Malawi, bringing together a wide range of stakeholders such as national government representatives, estate managers, union delegates and unskilled tea industry workers. It analysed the main issues facing the tea industry and the people involved in it, then drafted suggestions to reduce the risks they face and provide further inputs into the Malawi2020 Roadmap. 


\section{CONTENTS}

Executive Summary: key takeaways........................................... 4

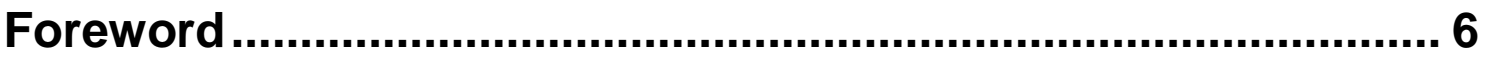

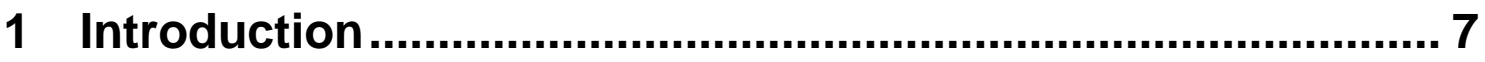

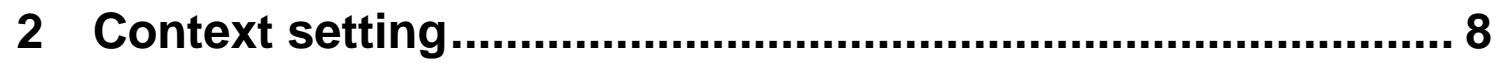

3 Findings from the VRA ........................................................ 10

3.1 Step 1 - Initial Vulnerability Assessment ..................................................... 11

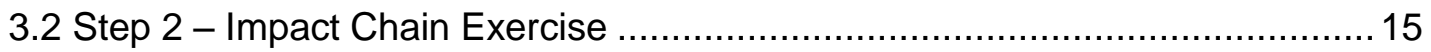

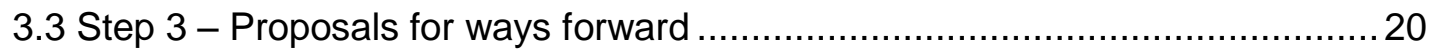

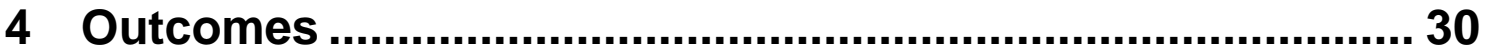

4.1 Issues directly related to Malawi2020 …...................................................... 30

4.2 Issues relating to the work of Oxfam in Malawi.............................................. 31

4.3 Issues relating to Oxfam's Economic Justice team and the Resilience Knowledge Hub.

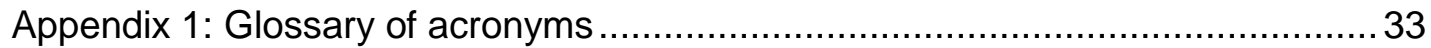

Appendix 2: Original list of hazards and issues ............................................... 34

Appendix 3: List of knowledge group members and facilitators ........................... 36

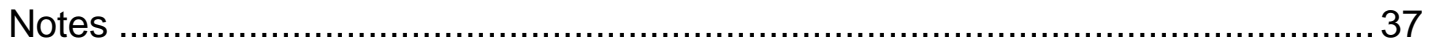




\section{ACKNOWLEDGEMENTS}

This report was written by Daniel Morchain, Wolfgang Weinmann, Chimwemwe Kachepa Kamala, Helen Jeans, Hyton Lefu (Oxfam), Linda Mtegha-Kawamba (Ministry of Labour of Malawi) and Edward Thole (Circle for Integrated Community Development) in August 2016.

The Steering Committee members of Malawi2020 (IDH, TAML, ETP) provided insightful inputs to the process and contributed to its analysis. Likewise, tea-buying companies and brands who have signed a Memorandum of Understanding with Malawi2020 provided their relevant views into the process. Last but certainly not least, the participants of the VRA workshop in Mulanje (i.e. the Knowledge Group) contributed their expertise and directly shaped the analysis of the exercise. The Malawi2020 Vulnerability Risk Assessment exercise and this report would not have been possible without the open, honest contribution of all these actors - the authors thank them wholeheartedly for their engagement.

The Malawi2020 VRA work was co-funded by the Sustainable Trade Initiative (IDH), Utrecht, Netherlands. 


\section{EXECUTIVE SUMMARY: KEY TAKEAWAYS}

After about seven months of preparation and consultation with stakeholders, a Vulnerability and Risk Assessment (VRA) exercise was conducted in Mulanje in June 2016, in the context of the Malawi2020 Tea Revitalization Programme (Malawi2020), which aims to achieve a competitive, profitable tea industry that can provide living wages and living incomes for its workers by 2020 . The VRA sought to address the key hazards and issues affecting people and other stakeholders in the tea-growing 'landscape' of Mulanje and Thyolo in Southern Malawi. The two-day workshop brought together a wide range of stakeholders: from national government representatives to estate managers to union delegates to unskilled workers of the tea industry. This group analysed and prioritized what it considered to be the main issues facing the tea industry and the people who are involved in and dependent on it. It subsequently drafted a number of suggestions to reduce the risks they face. In doing so, the exercise aimed to validate Malawi2020's Roadmap and provide further inputs to it.

Another fundamental and strategic goal of the VRA was to open up a safe space for stakeholders to talk freely to one another and explore ways to overcome the challenges they face: common challenges that affect different stakeholders differently. This dialogue, which should be continued regularly in order to truly bring about benefits, also contributed to giving stakeholders a better understanding of the 'big picture' of the tea industry and the implications of each player's roles and actions within it.

The five key findings and 'takeaways' from the Malawi2020 VRA are:

- The exercise validated the Roadmap to a large extent, which is reassuring. The ways forward elaborated during the VRA in steps 2, 3 and 4 are just a sample of the many possible ways forward discussed during the two-day workshop. Conducting similar exercises in future (i.e. steps 2, 3 and 4 - after step 1 has provided the base on which to start) could help flesh out further activities to add to the Roadmap.

- The macro-level issues of 'population growth' and 'unresolved land issues' came up as highly relevant, and as having considerable negative impacts on several social groups. While these might seem to be beyond Malawi2020's scope, the Steering Committee should acknowledge them and develop a joint position on how the programme will engage with these - directly or indirectly.

- The 'soft' outcomes of the VRA - providing dialogue spaces for stakeholders, and particularly, bringing marginalized groups into the decision-making arena of Malawi2020 are as important, if not more so, than the resulting analysis. The VRA exercise should not be a one-off event, and it should be followed by a stakeholder engagement strategy that truly promotes the empowerment of marginalized groups within the industry, and sets clear roles and responsibilities for Malawi2020 partners in achieving this goal.

- Similarly, the VRA exercise revealed the need to significantly increase efforts to establish a regular dialogue with government bodies, which has been insufficient so far. This interaction is important because the goals of Malawi2020 will have repercussions beyond the tea industry (e.g. the impact of a living wage in the tea industry for other key crops, such as tobacco or cotton), and also because reaching the goals of Malawi2020 within the tea industry require and/or would benefit from a collaborative approach with government (e.g. issues of basic service provision in tea estates and in the communities outside them).

- It was often argued during the VRA that the quality of Malawi's tea, which is considered to be lower than that of teas from key competitor countries such as Kenya, India or Sri Lanka, was directly related to the low wages paid to labourers in Malawi's tea industry. This correlation, 
however, has not been properly established. This claim would also imply that higher prices for Malawian tea would directly result in higher wages in the industry - for which there is also no evidence, or at least none which has been presented. The truth behind low wages is likely to be more complex than this. Malawi2020 should try to identify obstacles and leverage points to reach higher wages in the industry, and require all its key stakeholders to focus on efforts to achieve the desired outcomes of its different 'pillars' and workstreams - hence the need for action and commitment of all sides.

While the Malawi2020 VRA has provided and will continue to provide valuable input to the Steering Committee, its signatories and other stakeholders of the tea industry, it is important to remember that the exercise's framing and its analysis were carried out by a group of about 30 people - albeit carefully selected - in a period of two days. Its findings, as described in this report, should be read with that in mind.

Some of the findings of this report could be further developed through additional discussions with stakeholders, either in the form of individual interviews or in group settings. Likewise, conducting VRAs in future phases of Malawi2020 (e.g. annually) could provide an opportunity to qualitatively assess the progress of vulnerability-reduction efforts in the different stages of the project's implementation, as well as the impact of attaining Malawi2020's interim goals vis-a-vis the vulnerability of social groups. 


\section{FOREWORD}

One good reason to spend time and resources conducting a VRA is to shake things up a little bit, get people to hear new perspectives, and challenge the way they think about and do things. A researcher from a Norwegian university wrote:

‘...as long as [climate change adaptation] literature and policies are conceptualized within existing national and international development policies and dominated by approaches that narrowly address vulnerability, they will continue to promote responses to the symptoms rather than the causes of vulnerability, and may exacerbate inequities and power asymmetries that hinder or delay local adaptation efforts.'

The Malawi2020 Tea Revitalization Programme (Malawi2020) offers a unique opportunity to challenge the ways things are normally done; to look at the bigger picture of the role of the tea industry in Malawi - its potential, its duties, its opportunities; to lead the way in being socially responsible, just and fair. Malawi2020 is an opportunity for industry, labourers and government to rethink, jointly, what equitable development could look like. This report has been written with that in mind: with the ambition to take a small step towards the goal that Malawi2020 has set and that everybody needs to believe in and fight for.

\section{'I feel we are [now] better aligned.'}

\section{- Tea estate manager}




\section{INTRODUCTION}

In September 2015, a Malawi2020 Planning Session was held in Blantyre. There, Oxfam's David Bright (Head of Economic Justice) presented the Vulnerability and Risk Assessment ${ }^{2}$ (VRA) methodology as a tool used by Oxfam programmes to identify key issues and design according to the needs of the most marginalized and vulnerable groups of people. Oxfam also uses the VRA as a way to build bridges and trust among stakeholders that would not normally have the opportunity to talk to one another. The VRA was warmly welcomed by Malawi2020 partners, because it was seen as an opportunity to explore and better understand the underlying risks and vulnerabilities that the tea industry and that its workers and other people living in the 'tea landscape' are facing. This better-informed understanding - and understanding resulting from a joint analysis by a broad range of stakeholders - would serve both to validate and to challenge the assumptions of the Malawi2020 programme and its Roadmap.

Soon after, it was agreed that a VRA would be conducted in the context of Malawi2020, and in November 2015 we started contacting stakeholders in Malawi and abroad (abroad mostly tea buyers and traders) to explain the purpose of this exercise and bring them on board - either by their direct participation in the workshop that would take place in Mulanje, or by giving them the opportunity to input into the framing of the context and setting the scene for the VRA analysis. The main hard output of this VRA preparatory phase from November 2015 to June 2016 consisted of producing the lists of key 'hazards and issues' and of 'social groups and stakeholders' that would structure the analysis; whereas the main soft outputs of the process were to make stakeholders aware and increase their ownership of the joint analytical process and action planning, as well as to strengthen the participatory, democratic nature of Malawi2020.

On 9-10 June 2016, a VRA exercise was conducted in Mulanje with a select group of stakeholders (i.e. the Knowledge Group ${ }^{3}$ ), who jointly shaped the findings of the exercise. The VRA aims to develop a common understanding among a wide range of stakeholders about the main hazards and issues affecting people in a social-ecological landscape, and subsequently to jointly design measures to reduce risk, enhance well-being and promote resilient development in that landscape. While the Malawi2020 VRA would ideally have been conducted at the beginning of the project to help shape its Roadmap, the Steering Committee rightly considered it worthwhile to conduct the VRA during the second year of the programme, because its findings could still influence and inform the Roadmap. Furthermore, the initiative provided the additional benefit of bringing together - and hopefully creating greater dialogue and closer relations between - the broad spectrum of stakeholders that need to work together in Malawi2020, but do not always do so.

In the VRA exercise in Mulanje, key stakeholders from the Malawian tea industry were brought together to share their views and learn from one another about the risks and opportunities they see for the economic and social sustainability of the industry. The backdrop of this exercise is Malawi2020's objective to establish a 'living wage' for tea industry workers.

The specific objectives of the Malawi VRA were to:

- Conduct a landscape-level vulnerability assessment to promote inclusive and effective decision making;

- Build accountability and ownership of stakeholders - from community members to government authorities to private sector to academia;

- Use a participatory process to challenge the status quo and to build consensus;

- Build capacity of communities, local organizations and other formal and non-formal groups, NGOs and local governments; and 
- Make findings useful and usable in development planning, and promote transformational change.

This report collects the findings from the VRA exercise in Mulanje, considers how these may validate and/or inform the Malawi2020 Roadmap, and explores whether its outcomes may offer new ideas regarding policy and practice to the tea industry, as well as to Oxfam's work in Malawi and globally.

As this report brings together the views of a large number of stakeholders who participated in the VRA, we advise (as we normally do in other VRA processes) wide dissemination of the report and related communications products such as blogs, e.g. through the Malawi2020 website, the website of Steering Committee members, including Oxfam, and to relevant stakeholders in Malawi that have limited or no access to the internet. ${ }^{4}$

\section{CONTEXT SETTING}

Oxfam began work in the tea sector in collaboration with the Sustainable Trade Initiative IDH/Netherlands and Ethical Tea Partnership (ETP) to undertake research on low wages in the tea industry. In 2013, Oxfam co-published the report Understanding Wage Issues in the Tea Industry ${ }^{5}$ which highlighted the extent and severity of low wages in the sector - including in Malawi, where wages were below the extreme poverty line.

The findings of the 2013 study caused great concern but were accepted by all stakeholders. This provided a platform for a collective commitment to tackle low wages. However, raising wages in Malawi is challenging because the domestic industry produces a low-quality, low-price tea, and faces barriers to making the necessary investments to improve productivity and profitability - which are the basis to support higher wages.

Since the publication of the report, Oxfam has worked with ETP, Tea Association of Malawi (TAML) and IDH to develop the Malawi 2020 Tea Revitalization Programme (Malawi2020) working towards a competitive tea industry with living wages and living incomes.

The rationale for focusing on Malawi is that:

- Malawi is one of the world's poorest countries: $62 \%$ of Malawians live below the World Bank's extreme poverty line, and about $50 \%$ of all children are stunted.

- The tea industry is the largest formal sector employer in the country, employing 50,000 workers, evenly split between women and men. Other major employers are sugar and tobacco, where wages are also very low.

- Wages were found to be below the international extreme poverty line at household level, and below the national poverty line, despite meeting the legal minimum wage.

Malawi is Africa's second-biggest tea producer and a significant supplier to the UK market; it is of particular interest to ETP, Fairtrade, UTZ (a certification company promoting sustainable farming) and Rainforest ( $90 \%$ of Malawian tea is certified by any one of the certifiers). Twentyone estates, owned by eight different producer groups, grow $90 \%$ of Malawian tea.

The overall aim of this multi-stakeholder partnership is to achieve a competitive and profitable Malawian tea industry where workers earn a living wage and smallholders earn a living income. Malawi2020 also aims for significant improvements in general working and living conditions of tea-estate workers, especially women. The programme is supported by companies all along the tea value chain: producers, brokers and traders, tea buyers and retailers, as well as unions, NGOs, international donors and government agencies. 
Malawi2020, which is the first programme of its kind in the tea industry, has six intended key outcomes:

1. An industry that is investing in its future and its workforce.

2. Significant improvement in wages and benefits for workers - supply chain commitment to a living wage by 2020 .

3. Improvements in smallholder farming practices, yields, quality, income, and income diversification.

4. A healthier, motivated and productive workforce, with greater opportunities for women.

5. An improved wage-setting process with greater worker representation.

6. Sustainable energy use and improved environment.

Oxfam is responsible for four 'workstreams' to achieve the above outcomes, especially around ensuring that all stakeholders understand each other's challenges and opportunities and work together towards common solutions. Creating this enabling environment starts from a thorough risk and vulnerability analysis where all key stakeholders - especially the most vulnerable and marginalized groups such as workers, smallholders and women - have a say in identifying the risks and threats faced by the Malawian tea industry, and furthermore have a voice in prioritizing issues and designing ways forward. The VRA exercise conducted in Mulanje is critical in that it promotes multi-stakeholder interactions to strengthen the architecture of the Malawi2020 work and can promote collaborative actions to enrich the programme's existing Roadmap.

\section{'I didn't realize that pluckers do not have knowledge of the value chain.’}

\section{- Knowledge Group member}




\section{FINDINGS FROM THE VRA}

In October 2015, we started a consultation with all key stakeholders in the Malawi2020 initiative aimed at identifying the main hazards and issues, and the main social groups inhabiting the Mulanje and Thyolo 'tea landscape'. While it was rather easy to agree on the list of 12 or so social groups to further analyse during the VRA, the consulted stakeholders produced an initial list of more than 40 hazards and issues. To run the VRA in the space of just two days, we needed to reduce that list to about 12 to 15 hazards and issues, which we did by voting (we ended up with 17). The final list of hazards and issues and of social groups, as agreed by the Knowledge Group, served as the foundation of the analysis of the VRA. They are listed in Tables 1 and 2 below.

Table 1: Key hazards and issues impacting the Thyolo and Mulanje landscape

Ageing tea bushes/high cost of replanting

Climate change: changing and uncertain weather patterns (esp. rain)/drought/high temperatures and heatwaves/floods

Costly logistics and poor infrastructure

Difficult access to finance

Fast-growing population: food insecurity, malnutrition, poor health, conflict over land

Harsh treatment by $\operatorname{capitaos}^{6}$ (including sexual harassment/exploitation) and inadequate channels to raise issues/social pressures to keep issue silent

High costs of inputs (other than labour)

Inconsistent adoption of improved labour conditions by producers

Increased mechanization of tea plucking: Unemployment

Insufficient and underutilized irrigation systems for tea and other crops

Insufficient consideration of gender in policies that apply to the tea industry

Local-level impact: increased trends of deforestation/soil depletion and erosion/further encroachment onto Mount Mulanje

Poor representation of smallholder tea growers (SHTG) in decision-making processes/low worker representation

Steep price fluctuation/global oversupply - including Kenya's overproduction and Tanzania and Uganda's replanting programmes/domestic institutions lack of influence in global market

Unresolved land issues

Unsustainable (high) wages: loss of competitiveness

Unsustainable (low) wages: food insecurity, poverty 
Table 2: Key social groups and stakeholders inhabiting or operating in the Thyolo and Mulanje landscape ${ }^{7}$

Children under 14

Community entrepreneurs

Estate employed + SHTG + diversified farmers

Estates

SHTG + diversified farmers

SHTG women-headed households (hh)

Skilled labourers (men)

Skilled labourers (women)

Unskilled labourers (men)

Unskilled labourers (women)

Workers with HIV/AIDS, elderly, people with disabilities (PWD)

Young people (14-18)

The following sub-sections describe the findings from the four steps of the VRA conducted in Mulanje.

\subsection{STEP 1 - INITIAL VULNERABILITY ASSESSMENT}

The first step of the VRA is to determine the initial vulnerability of each social group or stakeholder to every hazard or issue. This is done through a group discussion around exposure - asking the question: 'What is the extent to which a social group could potentially be affected or damaged by the occurrence of a hazard or an issue?' - and around sensitivity: 'What has been the actual impact of a hazard or issue on a social group over the past 15 years?'

Exposure and sensitivity were assessed by the Knowledge Group ${ }^{8}$ on a scale from low (green), medium (yellow), high (orange) to very high (red). Figure 1 below plots the level of vulnerability of each social group or stakeholder to each hazard or issue. The vulnerability level is obtained as a direct correlation between exposure and sensitivity - and is categorized using the same four levels and colours described above.

It should be noted that this figure does not systematically prioritize or rank the hazards and issues - it simply couldn't. The reason for this is that social groups and stakeholders have very different levels of vulnerabilities to the same hazard or issue, and therefore ranking hazards would necessarily imply giving more importance to some social groups or stakeholders than others. That is, clearly, unacceptable and would be unethical (e.g. how do you rank unskilled women labourers versus children under 14 versus workers with HIV/AIDS?). What the vulnerability matrix does do, however, is offer a sort of simplified gradation of the interaction 
between the factors that determine the vulnerability of social groups and stakeholders. This understanding is fundamental for designing and implementing responses.

Figure 1: Initial Vulnerability Assessment matrix

\begin{tabular}{|c|c|c|c|c|c|c|c|c|c|c|c|c|c|c|c|c|c|}
\hline Unique reference & 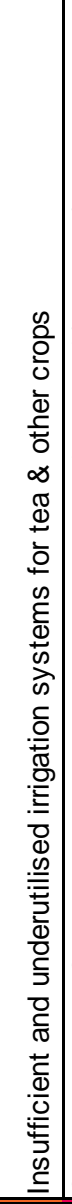 & 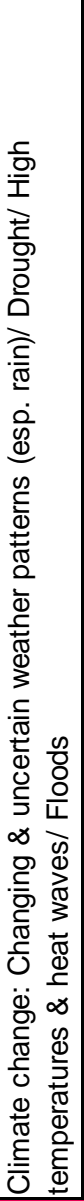 & 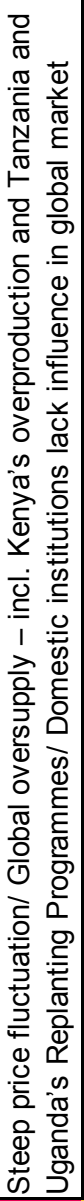 & 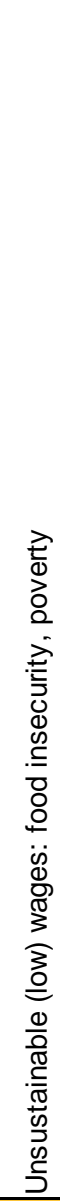 & 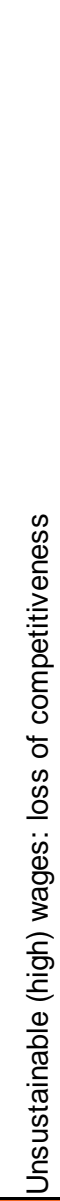 & 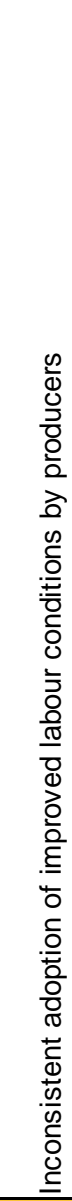 & 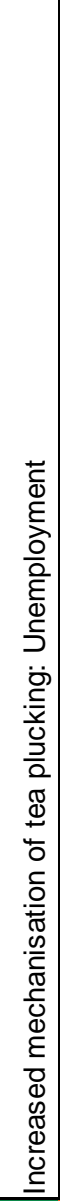 & 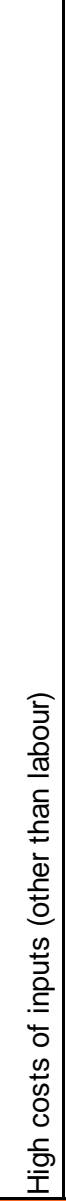 & 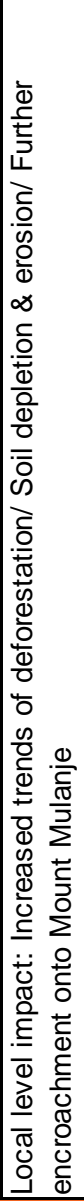 & 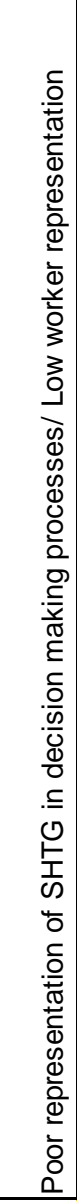 & 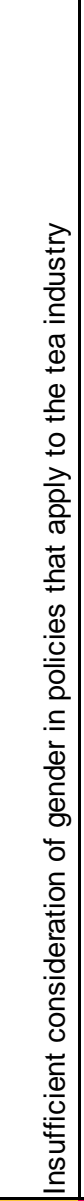 & 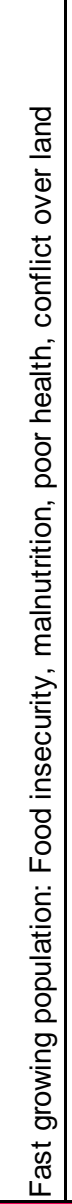 & 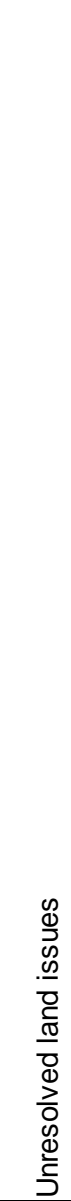 & 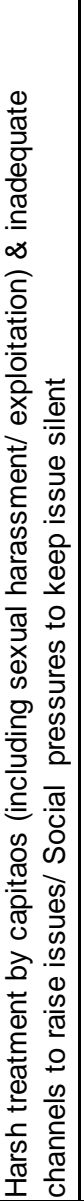 & 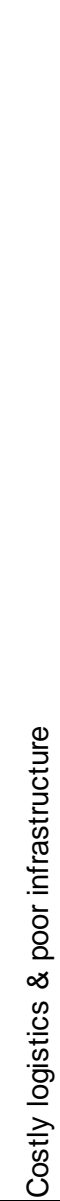 & 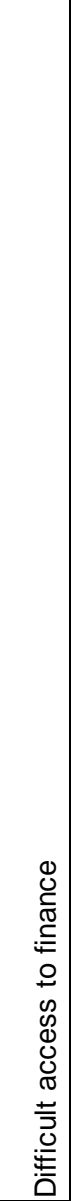 & 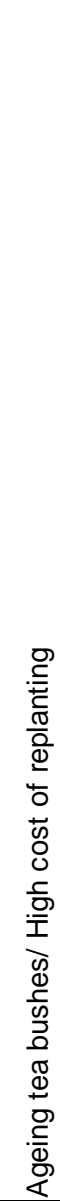 \\
\hline Estates & 1 & 0 & 0 & 2 & 1 & 2 & 3 & 1 & 1 & $\mathrm{~N} / \mathrm{A}$ & 2 & 0 & 0 & 2 & 0 & 1 & 0 \\
\hline $\begin{array}{l}\text { Estate employed + SHTG + } \\
\text { diversified farmer }\end{array}$ & 2 & 0 & 2 & 2 & 2 & 1 & 2 & 0 & 1 & 1 & 3 & 0 & 1 & 2 & 1 & 1 & 0 \\
\hline SHTG + diversified farmer & 2 & 0 & 2 & 1 & 3 & 2 & 3 & 0 & 1 & 0 & 2 & 0 & 0 & $\mathrm{~N} / \mathrm{A}$ & 0 & 0 & 0 \\
\hline SHTG women headed hh & 2 & 0 & 2 & 1 & 2 & 2 & 1 & 0 & 1 & 0 & 0 & 0 & 0 & $\mathrm{~N} / \mathrm{A}$ & 0 & 0 & 0 \\
\hline Skilled labourers (men) & 1 & 1 & 2 & 3 & 3 & 3 & 3 & 3 & 3 & 2 & $\mathrm{~N} / \mathrm{A}$ & 1 & 3 & $\mathrm{~N} / \mathrm{A}$ & 3 & $N / A$ & 2 \\
\hline Skilled labourers (women) & 1 & 1 & 2 & 1 & 3 & 3 & 3 & 3 & 3 & 2 & 1 & 1 & 3 & $\mathrm{~N} / \mathrm{A}$ & 3 & $\mathrm{~N} / \mathrm{A}$ & 2 \\
\hline Unskilled labourers (men) & 1 & 1 & 1 & 1 & 2 & 2 & 2 & 3 & 3 & 2 & $\mathrm{~N} / \mathrm{A}$ & 1 & 2 & $\mathrm{~N} / \mathrm{A}$ & 2 & $N / A$ & 2 \\
\hline Unskilled labourers (women) & 1 & 1 & 1 & 0 & 2 & 2 & 2 & 3 & 3 & 2 & 1 & 1 & 2 & 1 & 2 & $\mathrm{~N} / \mathrm{A}$ & 2 \\
\hline Young persons (14-18) & 2 & 2 & 2 & 0 & 3 & $\mathrm{~N} / \mathrm{A}$ & 2 & 0 & 1 & 2 & 2 & 0 & $N / A$ & $\mathrm{~N} / \mathrm{A}$ & 2 & $\mathrm{~N} / \mathrm{A}$ & 3 \\
\hline Children under 14 & 2 & 2 & 2 & 0 & 3 & $\mathrm{~N} / \mathrm{A}$ & 2 & 1 & 1 & 2 & 2 & 0 & $\mathrm{~N} / \mathrm{A}$ & $\mathrm{N} / \mathrm{A}$ & 2 & $\mathrm{~N} / \mathrm{A}$ & 3 \\
\hline $\begin{array}{l}\text { Workers with HIV/AIDS, } \\
\text { elderly, PWD }\end{array}$ & 1 & 1 & 2 & 0 & 2 & 1 & 1 & 2 & 2 & 1 & 1 & 0 & 2 & 2 & 0 & $N / A$ & 2 \\
\hline Community entrepreneurs & 2 & 2 & 2 & 2 & 2 & $N / A$ & 2 & 2 & 2 & 3 & $\mathrm{~N} / \mathrm{A}$ & 3 & 3 & $\mathrm{~N} / \mathrm{A}$ & 1 & $N / A$ & 3 \\
\hline
\end{tabular}

Some of the key findings from this first step of the VRA are presented below.

First, here is a brief overview of the range of impacts on social groups/stakeholders:

- The vulnerability of tea estates to a considerable number of hazards was considered to be high or very high, which was surprising to some stakeholders.

- SHTG, unsurprisingly, fare worse than estates because of their comparatively lower capacity to respond to market forces or to influence them. Within SHTG, women-headed households are particularly vulnerable. On the other hand, those SHTG who also provide their labour to 
estates are overall less vulnerable (partly due to having diverse sources of income, but also to being more networked).

- The vulnerability of labourers is more determined by the type of work they do (skilled workers are less vulnerable than unskilled) than their gender; however, women are slightly more vulnerable than men in relation to some hazards - e.g. harsh treatment and harassment, which applies mostly to unskilled labourers. In general, however, the analysis revealed that women were not significantly more vulnerable than their male counterparts (e.g. unskilled women labourers were not significantly more vulnerable than unskilled men labourers).

- Skilled labourers (particularly men) can somewhat more easily find and move between jobs. By not being directly affected by some hazards in the way that SHTG are, their overall vulnerability is lower than that of SHTG.

- Elderly people, people with disabilities and people with HIV/AIDS have an even higher vulnerability to low wages than unskilled workers, as they tend to be the first to lose their jobs during economic hardships. In return, they face food insecurity and poverty. Additionally, because of their age and status, they sometimes have insufficient stamina to maintain their jobs. Furthermore, this group feels they are less supported by government than other groups, such as young people, increasing their vulnerability to a range of factors.

- Young people and children's scale of vulnerability is similar across the range of hazards. Their vulnerability, particularly children's, largely reflects their parents' considerable dependence on the tea industry and the limited alternative sources of livelihood.

- Community entrepreneurs was overall the least vulnerable group, as they are not necessarily directly impacted by the key hazards affecting the tea industry. It is possible, though, that this lower vulnerability results from the exclusion from the assessment of the hazards that they may be most directly affected by (as we focused on hazards faced by the tea industry).

Other findings from the hazards identified as generating high levels of vulnerability across a wide number of social groups/stakeholders are:

- The three hazards and issues with highest vulnerability across different social groups - i.e. more red cells - are: growing population (first); climate change, tied with steep price fluctuation/global oversupply/domestic institutions lack of influence in global market, tied with high cost of inputs (other than labour), tied with costly logistics and poor infrastructure, tied with ageing tea bushes (second); and unresolved land issues (third).

- The issues of fast-growing population and unresolved land issues (as well as limited availability of arable land) are creating social tensions. As a considerable portion of the arable land in Thyolo/Mulanje is used to cultivate tea at a large scale, there is increasing pressure on communities to encroach into estate land to cultivate for subsistence. This has resulted in tensions and conflicts with estate owners. One estate worker lamented that this is resulting in inadequate food intake and supply at household level.

- Climate change (with special attention given to drought, changing and uncertain rainfall patterns, higher temperatures, heatwaves and floods) heavily impacts all tea producers, as there are few adaptation measures in place. The group concluded that SHTG were equally exposed to climate change than estates, but the sensitivity of SHTG was considered lower (in relation to tea production exclusively) because many SHTG have a more diverse source of income. ${ }^{9}$ However, the one social group which doesn't have much crop diversification is the women-headed households, so their vulnerability is higher than that of other SHTG. In relation to labourers, they feel the impact of climate change slightly indirectly, possibly in the form of fewer jobs being available, as well as impacts on their health as a result of higher temperatures and heatwaves while working in the fields. These impacts would be higher for elderly people, people with disabilities and workers with HIV/AIDS.

The group also discussed whether young people and children should be considered to be more vulnerable to climate change impacts over their lifetimes, considering the risk that the 
tea industry would decline or fail in the longer term, as well as other climate change impacts. The conclusion during this short assessment was 'no', as young people and children mostly do not want to work in the tea industry anyway, and are possibly better adapted to looking for and finding alternative livelihoods.

- The group concluded that there is a correlation between low wages and food insecurity and poverty, particularly for women-headed households, youths/children and for people who don't grow/sell tea or don't have income-generating activities other than employment as unskilled labourers in estates. There is, at the same time, pressure on the industry to not increase wages in order to remain competitive in the global market. Higher wages would increase costs of production (which now amount to about $40 \%$ of total costs, according to an estate manager) and, as the buyer determines the price, estates have little room to manoeuvre; even with a direct buying scheme the price is a market price. Furthermore, one estate owner felt that because Malawi is a landlocked country, costs of logistics and transportation are relatively high, which additionally complicates wage increases. The common message, nevertheless, is the need to address the living wage agenda as a win-win approach for the industry and its labourers: higher wages benefit the workers, but they should also benefit the industry as a whole - e.g. showing that a living wage can bring benefits to the product from a quality, as well as from social and marketing perspectives.

- The high cost of agricultural inputs (other than labour) has a major negative impact on SHTG, as they are unable to absorb these costs and have a lower bargaining power than estates. Although estates are less vulnerable than SHTG on this respect, they also consider this an important issue affecting their viability.

- Poor representation of SHTG in decision-making processes has important negative implications for these groups, including failure to negotiate proper or attractive trading deals with buyers.

- The issue of harsh treatment and harassment by capitaos and the difficulties involved in raising these issues came up as an important driver of vulnerability, especially for unskilled women labourers. Some of the manifestations of this issue discussed during the VRA exercise were sexual exploitation, capitaos underpaying women, and victimization of worker representatives by employers and capitaos making it very difficult for them to represent the grievances of estate workers to management. At first, when discussing the issue of harassment, the subgroup working on it understood it as relating exclusively to sexual harassment and only affecting women, which explains the N/A cells in the table. In the subsequent plenary, the larger group agreed that harassment issues do affect both men and women labourers (though they almost exclusively affect unskilled labourers).

- Difficult access to finance is a major issue for SHTG. Estates, somewhat surprisingly, also highlighted their difficulty in getting access to finance.

- Ageing tea bushes is a major source of risk and vulnerability for producers large and small. Interestingly, estates have in general older tea bushes than SHTG (more than 50 years old, with declining production and quality), as SHTG started growing tea later. However, estates have a higher capacity to manage and renew plantations than SHTG. That said, there is a pressing need for a major revamping in most estates, which is ongoing in phases and which currently puts additional financial stress on estates.

On the basis of the 'big picture' overview provided by step 1 of the VRA, the Knowledge Group voted on the four hazards and issues it considered to be the most relevant. These hazards and issues were then further analysed during the VRA's steps 2, 3 and 4. This selection, obviously, does not mean that the other hazards and issues are not considered to be relevant; however, prioritization was necessary given the limited time for the exercise. The four hazards and issues taken up for further analysis were (not in order of relevance):

1. Climate change: Four social groups or stakeholders have 'very high vulnerability' to climate change impacts (i.e. four red cells in the matrix), and five have 'high vulnerability' (i.e. five orange cells in the matrix). Furthermore, climate change was considered by the group to be 
an important threat to the existence of the tea industry in the medium term, with impacts being felt already.

2. Low wages, harsh treatment and harassment: These were categorized as separate issues in step 1, but the Knowledge Group decided to address them jointly in the subsequent steps because both were considered highly relevant and the group did not want to drop either one from steps 2, 3 and 4. Low wages has four red cells and four orange cells. Harsh treatment and harassment was considered a very important issue for unskilled women labourers in particular.

3. Ageing tea bushes/high costs of replanting: This issue has four red cells. At first the Knowledge Group did not consider it to be one of the main issues to analyse further because it was seen to only affect producers. However, after highlighting the indirect impacts on labourers, the group agreed to select this as one of the four key issues.

4. Costly logistics and poor infrastructure: This issue has four red cells and two orange cells. Similarly to 'ageing tea bushes', this issue was included in the final list after discussion within the Knowledge Group about its indirect impact on labourers.

Two other issues, which were not voted to be further analysed but which showed 'very high' vulnerability of many social groups, are worth mentioning at this stage. One is fast-growing population (leading to food insecurity, malnutrition, poor health, conflict over land, among others). This issue had a record seven red cells and four orange cells, but it was not selected for the exercise because of the relatively low impact that Malawi2020 can have on it. Similarly, unresolved land issues had three red cells and one orange cell, but the role Malawi2020 could play in addressing this was again thought to be considerably lower than it was for the other issues selected.

The fact that the two issues above were not selected for further analysis should not, however, be misunderstood. Both are fundamental to the well-being of the populations of Mulanje and Thyolo and to the sustainability of the tea industry. As such, Malawi2020 - particularly its Steering Committee - needs to acknowledge them and decide on a strategy to approach these issues, whether directly (which may not be advisable, considering the arguments above), or indirectly (e.g. through advocacy with government bodies).

\section{'There is a lot more knowledge and experience in smallholders that must be taken on board.'}

\section{- Knowledge Group member}

\subsection{STEP 2 - IMPACT CHAIN EXERCISE}

The Impact Chain Exercise allows the Knowledge Group to assess the impacts of hazards and issues and their implications over time, by mapping their impacts throughout the different social groups and, indeed, the system (i.e. the landscape and beyond). This step also generates initial ideas about measures that can be taken to reduce the vulnerability of social groups and promote their resilience.

\subsubsection{Climate change}

The impact chain focusing on climate change encompassed the following climate-related impacts: drought; heavy rain and floods; high temperatures and heatwaves.

Drought and floods affect tea production in similar ways. For instance, floods as well as heavy rains lead to soil erosion, which exposes the roots of tea bushes and prevents or interrupts 'field 
operations' such as fertilizing. This has a short- to long-term impact on tea production by reducing the quantity and quality of tea produced. Drought can cause tea bushes to die, and also reduces the quantity and quality of tea produced.

Both of these impacts lead to low prices for tea and, as a consequence, reduced income for tea producers and all tea workers across the board. For instance, in episodes of drought, workers tend to be laid off more than in times of heavy rain or floods; and in both cases the incomes of smallholders and tea workers are reduced. Unskilled workers can be more affected by droughts, as the work required by estates tends to be more mechanized at this time; whereas demand for workers with specific skills is less affected. During heavy rain and floods there tends to be higher levels of absenteeism due to transport difficulties getting to fields/factories, and domestic pressures caused by these impacts.

Drought and heavy rain/floods puts an upward pressure on food prices, while at the same time incomes drop (as explained above). This combination of circumstances increases food insecurity, leading to malnutrition, especially among children under five. Maize, the staple food crop, in particular, becomes expensive as it is vulnerable to floods and drought. Furthermore, shrinking incomes can result in parents/carers being unable to pay school and college fees, resulting in loss of educational opportunities for young people.

Droughts reduce access to water for domestic use at the household level. This leads to higher incidence of some diseases, including cholera. Floods and heavy rain also increase the incidence of disease, especially where there is limited or no access to sanitation services and infrastructure. In times of drought, women have to go further to collect water, which reduces the time they have in the home and increases their overall burden.

Additionally, both impacts cause the temporary dislocation of people. Temporary separation of families is higher as a result of floods and heavy rain. Floods and heavy rain have also resulted in the loss of infrastructure, including loss of homes, schools and roads. Transportation is likewise affected, making it hard to get tea to the market and workers to the factory/plantations. Hydropower generation is also affected, leading to interrupted or more irregular power supply.

Heatwaves and high temperatures also reduce the quality of tea produced and lead to lower prices and - subsequently - lower incomes.

There is very limited access to weather information for both small and large tea producers (other sectors seem to be better served by meteorological information services). The lack of weather information leads to uncertainty and lack of proactive measures to reduce impacts of weather events, especially by smallholders.

Over the long term, if unaddressed, this set of climatic impacts could lead to the diminishment of the tea sector or - eventually - its ultimate cessation. By comparison, the relationship between the government and the tea industry seems more distant than is the case with other key agricultural commodity industries in Malawi (e.g. tobacco and cotton). The reasons for this are complex, but one issue raised by tea estate managers is that the tea sector is seen by the government as the responsibility of the estates, and as such there are limited concerted efforts from government to help the tea sector adapt to climate change impacts. On the other hand, government voices within the Knowledge Group hinted at the tea industry being unwilling to open up and collaborate with government as partners.

The possible reduction or failure of the tea sector as a result of climate change effects would impact small holders, estates and the economy of Malawi. Smallholders will lose incomes, jobs, and the support they get from estates including education and access to some primary healthcare services. Increased poverty levels will also result in struggling local economies. Estates may be forced to reduce production or close down altogether, which, on the other hand, may have the positive impact of making land available for other crops and enterprises. This, however, would require substantial short- to long-term investment in the diversification of the 
agricultural sector. Under this scenario, the Malawian economy would shrink at least in the short to medium term and employment levels would drop, further increasing pressure on other sectors. Social and political unrest could also be possible under this scenario.

\subsubsection{Low wages, harsh treatment and harassment}

The issues of 'Unsustainable low wages leading to food insecurity and poverty' and 'Harsh treatment by capitaos (including sexual harassment/exploitation) and inadequate channels to raise issues/social pressures to keep issue silent' are addressed jointly under this and in subsequent sections. The reason for this is merely pragmatic, as the Knowledge Group could break into no more than four groups for steps $2-3$, and it was felt important to take both issues beyond step 1 in the VRA discussion. Hence they had to be merged into one issue, as they are more clearly related than the other hazards and issues taken forward. In the discussion, however, we have tried to differentiate them as appropriate, both for the sake of clarity and recognizing that they are clearly distinct issues.

The key problems identified by the group and their impacts on the tea sector are described below:

In relation to low wages:

- Little flow of information between employers and workers - workers expressed ignorance of the fact that any income realized from the sale of tea is also used to cover other aspects of the business, i.e. transportation, storage, processing costs as well as replacing ageing tea trees.

- Wage-fixing policy does not favour increase in wages; rather it pulls wages downwards, towards the minimum wage benchmark.

- High tea prices on the world market do not result in an automatic increase in wages - there is no trickle-down effect.

- Collective bargaining agreements are not in place. This mostly affects unskilled men and women labourers, as they have less bargaining power outside the collective bargaining agreement $(\mathrm{CBA})^{10}$. Skilled women and men are at a comparative advantage, as even with the absence of CBA, they are more likely to be able to bargain for better wages because their skills are in demand.

- Employers feel low wages are the result of a slowing economy and of subsequent difficulties in keeping the industry running. As such, employers feel increasing wages is beyond their control (i.e. it can only be the result of improving macro forces or government intervention).

- Breakdown of security - much of the income realized from sales is being used to increase security measures within and around the estates.

In relation to harsh treatment and harassment being experienced by women and men, especially among unskilled labourers:

- Minimum guidelines for estates and smallholder farmers on what constitutes harassment are always applied nor enforced - most estate workers are not aware that harassment is an offence, nor of the existence of guidelines and mechanisms to address this problem. Trade unions can also play a role in giving information and training their members about harassment in the workplace and its negative impact.

- Lack of knowledge of, and adherence to, conditions of service by workers as well as the capitaos - terms and conditions of service in the estates are not shared with workers. In some cases, capitaos either deliberately or inadvertently do not follow the established terms and conditions of service.

- Presence of threats and victimization of worker representatives by employers and capitaos makes it very difficult for worker mediators to represent the grievances of estate workers to management. 


\subsubsection{Ageing tea bushes}

Under the issues of 'ageing tea bushes' and 'high cost of replanting', major causes identified included drought, diseases and pests; the high cost of replanting, especially seedlings; cashflow problems; climate change impacts reducing the success of establishing new tea plantations (fields); and investment uncertainties enhanced by climate change impacts with regards to the four-year interval between planting new tea plants and the start of production. High inflation, crime, migration and political instability all put a negative pressure on willingness to invest.

These problems lead to the following impacts and challenges in the tea sector:

- Low yields, hence low exports and low profits, and less foreign exchange as well as lower imports.

- Low tea quality, hence less competitiveness of Malawian tea on the global markets, possibly leading to reduced income.

- Reduced employment opportunities; and reduced income for estates, communities and government - all of which affect the local economies.

\subsubsection{Logistics and infrastructure}

Under the issue of 'markets and logistics', some of the key challenges identified were poor roads and railways, which poses challenges in transporting tea and other products within the value chain; poor access to ports and markets that increases costs and shrinks profits; problems crossing borders leading to delays and tea pilferages; unreliable supply of electricity affecting the production process and reducing the quality of tea; poor communication infrastructure resulting in unreliable and broken-down communications; poor vehicles and warehousing leading to inappropriate transporting and storage of tea and other materials.

In relation to the tea sector, these challenges lead to:

- Theft of tea due to low patrolling by estates' security structures. This is a challenge mainly when the roads are inaccessible, especially during the rainy season, as tea cannot reach the warehouse or factory in time. These setbacks also result in delays in getting the tea to market, and hence lower revenues, which in turn may impact negatively on the volume of labourers recruited to work in estates.

- Poor condition of roads within estates leads to difficulties and delays in transporting tea/firewood from fields to warehouses. This in turn leads to reduced quality of tea and lower selling prices, also affecting the poor image of Malawian tea at the global level. This results in a shrinking tea industry, which is therefore unable to employ as many local people. Lack of employment opportunities, compounded by insufficient access to land to grow crops, fuels poverty among the local population.

- Low wages and loss of jobs are considered to be partly a consequence of the low price that Malawian tea fetches, due to the tea's (real or perceived) low quality and the poor infrastructure of the Malawian tea industry, which increases production costs. However, it is not clear to what extent these elements truly do push wages down, and if higher tea prices would correlate (directly or otherwise) with increased wages in the industry.

- Poor roads (inbound towards plantations) lead to difficulties in transporting agricultural inputs to estates, which can result in a late application of inputs. This inappropriate management of plantations can result in low and poor quality tea.

- Poor roads (outbound to market/port) also contribute to late deliveries of tea to markets, which results in tea pilferage and contributes to reduced revenues.

- Poor access to ports caused by congestion leads to high port charges due to overstay, warehousing and surcharges. These lead to reduced port calls by vessels and increases in penalties due to overstays. 
- Power outages force estates to use diesel generators, raising production costs and reducing the competitiveness of the Malawian tea industry. This has many effects, including the poor image of Malawian tea, loss of jobs and low revenues. The diesel generators also cause pollution and contribute to global warming and climate change.

- Unreliable internet and phone networks obstruct business deals and can result in missed market opportunities. Locally, people also have intermittent access to communications, which can jeopardize employment and trading opportunities. 


\subsection{STEP 3 - PROPOSALS FOR WAYS FORWARD}

Proposals for ways forward - also known in VRA methodology as 'adaptive capacity analysis' allow the Knowledge Group to explore further the measures to reduce vulnerability identified in the impact chain exercise, and to test their potential contribution to risk reduction and resilience over the longer term, by applying an adaptive capacity lens. The analysis considers the extent of the impacts to social groups and to the industry as a whole in the next ten years and beyond.

\subsubsection{Climate change}

The group produced a number of proposals that may reduce the impacts associated with climate change in Malawi's tea industry. They are:

- Recognition of the tea industry's contribution to the Malawian economy and people: the government needs to more explicitly recognize the value and contribution of the tea industry to the Malawian economy and people, and the private sector elements of the tea industry need to be more willing to open up and engage with governmental bodies. This shift in attitudes would potentially open up the sector to greater levels of external support and investment, as outlined below. It would also facilitate better support to the tea sector, e.g. the provision of extension services to smallholders.

- Implementation of national climate change law and policy: all stakeholders would benefit from the implementation of a comprehensive climate change policy that also addresses the needs of the tea industry. For example, national climate change planning and legislation could facilitate greater access to international support and finance for climate change adaptation investments such as integrated catchment protection and irrigation schemes. This would benefit the tea sector and other businesses as well as vulnerable people and communities.

- The provision of weather-related and other information targeted at the needs of tea producers (both smallholders and estates); this could be delivered through collaboration between government agencies, e.g. meteorological and agricultural departments, estate owners and smallholders. Gender-sensitive training would need to be provided, possibly by civil society groups working with relevant government agencies, to enable smallholders to understand and act in response to weather forecasts, which could be provided via mobile phones. Government-provided extension services should include training on how to adapt to climate change and adopt conservation practices.

- Diversification by smallholders to other high-value crops: this may increase smallholder income and income stability in the light of climate change impacts. This proposal requires further in-depth analysis of possible high-value crops, market opportunities and risks, and their suitability for SHTG in Mulanje and Thyolo, among other criteria.

- TAML could explore the possibility of facilitating the trial and uptake of drought-resistant tea varieties by estates and smallholders in ways that spread the risks and benefits for the sector as a whole.

- National government is addressing the need for more efficient energy provision. This could be complemented by the introduction of energy-saving cooking stoves for estate workers by tea estate owners/smallholders with support from civil society groups, including Oxfam. Tea estates would benefit from reduced encroachment to access firewood for cooking, whereas the stoves would reduce the overall pressure on firewood, thereby lessening deforestation while improving worker health, especially that of women workers who bear most of the burden of collecting firewood and cooking.

- Investment in irrigation systems could benefit smallholders and estates, and could promote the more sustainable use of groundwater in the longer term. National government wants to 
address this challenge. Further analysis and investment should support small-scale systems owned and run by smallholders and community members.

- Catchment management (including protection of forests, re/afforestation and soil conservation): as with irrigation, national government is aware of the challenges and needs. Further analysis and planning should consider small-scale activities that can be implemented quickly through local-level collaborations between estate owners, smallholders, local government and civil society. Such activities could be aimed at reducing flash flooding and other short-term, yet highly damaging, impacts. TAML could promote the sharing of good catchment management practices between estates and smallholders.

- The overall need for greater investment in infrastructure, including roads and domestic infrastructure (better water and sanitation for smallholders and tea workers), was identified.

- Health education would help households manage the health-related impacts of floods and droughts.

- Diversification of food preferences: there is a strong dependency on maize as a staple crop, especially for people living in Mulanje and Thyolo; however, maize is highly susceptible to climate change as compared to other crops. Diversifying food preferences requires cultural as well as other changes, and appropriate strategies need to be developed with the people most affected.

- Multi-stakeholder planning approaches such as that used in the VRA could facilitate crosssectoral commitment to larger-scale catchment management and irrigation schemes that address the short- and longer-term climate change impacts on tea production. TAML could act as a convener and broker of these processes.

\subsubsection{Low wages, harsh treatment and harassment}

The group produced a number of proposals that may reduce the impacts associated with unsustainable low wages, harsh treatment and harassment in Malawi's tea industry. The proposals are aimed at various players in the industry including producers, partners (especially trade union leaders), workers and labourers themselves, and policy makers. They are:

- Policy development on reducing harassment: currently there is no policy or legal provision governing harassment in the workplace. Considering that the malpractice is still going on, there is a clear need for a legal and policy framework on harassment in the workplace.

- Training of workers in various areas: industrial relations is a key component in labour and the workplace as a whole. What came up in this group's discussion is that most workers, including the capitaos, are not aware of various employee/employer-related obligations regarding the employment relationship, i.e. issues of hours of work, rest, maternity leave, sexual harassment, overtime, sick leave, ordinary leave etc. Awareness needs to be raised with employers to increase their accountability and with workers to ensure they know how to exercise their rights when these are threatened.

- Improving information flow within the estates: one of the participants, a worker, indicated that they were not aware that sales from tea are used to meet other costs of production within the estate, e.g. transport, storage etc. The workers' assumption has always been that the more tea the estate produces and sells, the higher the wages will, or rather should, be. Workers were unaware of the fact that this was not automatically the case. Information was not flowing within the estates on this fact, and this should be improved.

- Having in place and widely disseminating the minimum standard guidelines of the industry (or higher level) that appropriately minimize the risk of harassment.

- Stricter adherence to conditions of labour provision, e.g. working within the set, agreed hours.

The group focusing on 'low wages/harassment' further explored a number of impacts identified during the impact chain exercise, by applying the adaptive capacity thinking developed by the 
Africa Climate Change Resilience Alliance (ACCRA). The ACCRA framework recognizes five characteristics of adaptive capacity: 1) asset base; 2) institutions and entitlements; 3)

knowledge and information; 4) innovation; and 5) flexible, forward-looking decision making and governance. In order to apply this framework, the group identified one specific measure to take forward - 'to reach agreement on and implement sectorial wages' - and identified the elements needed from each of the five categories of adaptive capacity (as outlined below).

The following is an example of one way forward under the issue of 'unsustainably low wages': to reach agreement on and implement sectorial wages.

1. Assets:

- Motivated workforce - this normally results in improved productivity and has a positive impact on the business and the estate as a whole.

- Legal and policy framework - this is important as it is the guiding principle in doing business, for example in terms of trade policies, regulatory framework governing the employment relationship, wage-setting policies, etc.

2. Institutions:

- Estates and smallholders (organized as TAML) - they need to articulate what they feel is needed for business to flourish in a more coordinated manner, i.e. 'speak with one voice'.

- Trade unions - they need to be representative of the workers, and to be given adequate freedom to associate and organize without interference.

- Government institutions - the group members felt the list is longer than the one shown here; however, this shows the leading institutions, especially with regard to the tea sector:

- Agriculture - tea is an agricultural produce.

- Labour - tea production requires considerable labour; industrial and employment relations also need to be addressed under this category.

- Trade - tea is a trade commodity; proper trade deals and markets are needed for the produce to fetch a good price and be able to sustain business.

- Finance - fiscal space is critical for ensuring that businesses are able to make profits which can potentially trickle down to better wages for labourers. Harsh monetary and fiscal policies have a negative effect on sectorial wages.

- Transport - this is a key element, as tea is sold for the international market. Better and improved transport infrastructure are needed, both internally and externally. Good bilateral relations should be established with neighbouring countries, considering that Malawi is a landlocked country.

3. Knowledge and information:

- Historical data - historical data analysis is a good source of data for comparative analysis as this gives a basis of the current wage trends, and can help improve understanding of the reasons why wages have been low in the tea sector.

- Labour-force surveys - when conducted frequently they can provide adequate information on labour-market trends. They can be used as a source of data to compare wages in the various sectors of the economy as well as the market trends, and can help give an overall picture of the tea industry in relation to other key industries in the Malawian economy.

- Fiscal policies - constant revision of fiscal policies to address the present challenges is crucial. Key players need to have adequate information on the implications of policies being implemented and what they mean for business.

- Market trends - market trends are a good source of information as they act as key indicators for future planning. 
- Group seminars - raw data that cannot be formally collected can be sourced during discussions at group seminars.

4. Innovation:

- Quality Minimum Standards (across TAML) - a priority should be to set minimum standards across TAML that are negotiated without prejudice, in a fair and free manner.

- Incentives -benefits, bonuses, training, exchange programmes should be established and promoted.

- Productivity - mechanization of certain activities can improve productivity, which can bring in better returns in terms of wages. These areas should be explored and analysed.

5. Flexibility:

- Promote social dialogue - this is a key element in any industry, including tea. An open dialogue between partners eases tensions and minimizes risks of escalating disputes and industrial unrest.

- Encourage information-sharing across the sector - an interesting example of a gap identified in this respect during VRA discussions (as cited above) is that employees did not know that sales from produce of tea are also used to cover costs of production and transport. They thought that increased sales should automatically result in higher and better wages, but this information-sharing exercise allowed them to gain a more nuanced understanding of the complexity embedded in tea production. At present, there is no vertical information flow between stakeholders.

- Involve all key stakeholders in decision-making processes - selective participation defeats the purpose of business growth and sustainability. All key stakeholders need to be involved when making plans or changes

- Conduct open forum workshops - this is a great way of getting feedback upwards from the grassroots level. Issues of discrimination, victimization and sexual harassment can be dealt with (and amicable solutions can potentially be reached) if people are able to discuss and share experiences.

- Implement estate-to-estate experience sharing - different estates have different ways of handling issues related to employment relationships, and a cross-estate learning forum could present an opportunity for more formalized and homogenous responses, as well as for sharing constructive lessons about constructive employer-worker relations.

Members felt that an exploration of the five elements discussed above could promote the discussion of better, sustainable wages in the tea sector, as well as provide more safeguards for labourers and improve employer-worker relations.

\subsubsection{Ageing tea bushes}

The group produced a number of proposals that may reduce the impacts associated with ageing tea bushes and the high cost of replanting in Malawi's tea industry. They are:

- Phased replanting with drought resilient varieties.

- Investment in research and development in the tea sector.

- Investment in value addition, such as improved branding and exploring green tea production.

- Diversification of markets.

- Investment and improvement in marketing of Malawian tea.

As in the example in the sub-section above, we used ACCRA's framework to explore what is needed to address the challenge of ageing tea bushes and the high costs of replanting. The 
lists below identify those needs, divided into the five categories of adaptive capacity building, as shown below: 
Figure 2: Malawi2020 Roadmap

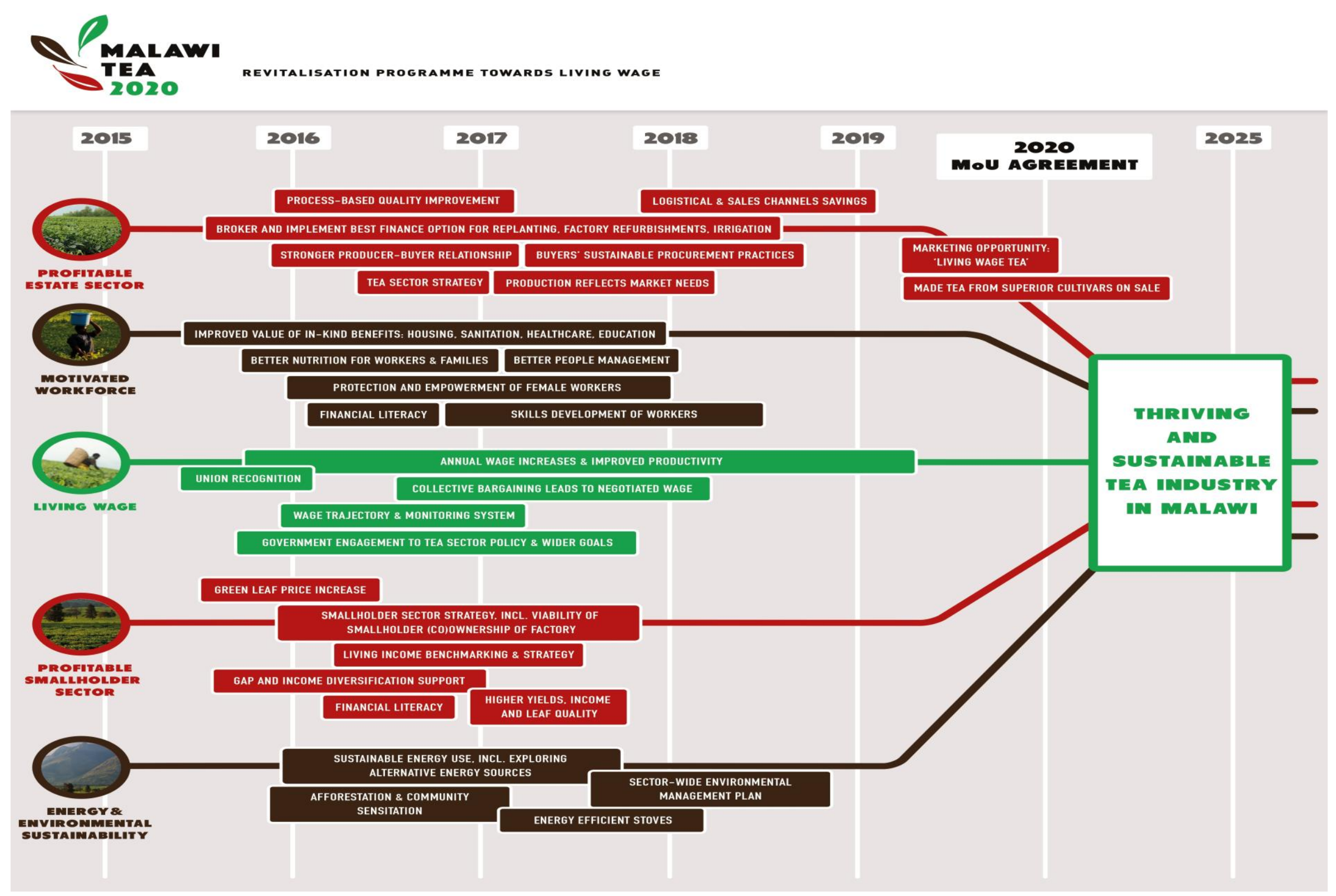


The VRA process now complements the original Roadmap analysis and design by highlighting risks, threats and opportunities of the tea industry and how they impact on different social groups, enabling a more detailed appreciation and analysis.

Thus it provides an additional input and contribution to strengthen the original Roadmap, identifying gaps and turning these into potential actions that would enhance the achievements of the Malawi2020 programme.

The following risks were identified as causing high vulnerabilities across several social groups and stakeholders (from Figure 1: Initial Vulnerability Assessment ${ }^{11}$ ):

\section{Fast-growing population}

2. Climate change

3. Costly logistics and high cost of inputs, and unresolved land issues

\section{Ageing tea bushes}

5. Unsustainable low wages

6. Difficult access to finance

\section{Poor representation of smallholders in decision-making processes}

Comparing these high risks with the existing Roadmap pillars and workstreams, there is a strong overlap indicating that Malawi2020 is already addressing these risks in a variety of ways (see Table 3 below). However, it is important to stress that the VRA process highlighted the interconnectivity of certain risks, which requires a systems thinking approach to tackle them. It is not clear if the existing Roadmap adequately caters for this approach, or whether the individual pillars function rather more separately. Furthermore, it is necessary to check if current workstreams such as 'Sector Policy' actually cover the risks/threats highlighted in the VRA process, e.g. around 'costly logistics'.

Whatever the case, though, an opportunity has definitely arisen to take up the findings of the VRA process to ensure a holistic programme in Malawi2020.

Nonetheless, two risks, 'population growth' and 'unresolved land issues', have no direct obvious connection to the Roadmap; further discussion is required on how to incorporate these into the Malawi2020 programme. 
Table 3: Are key risks identified in the VRA addressed by the Roadmap?

\begin{tabular}{|l|l|}
\hline Risk with high vulnerability levels & Roadmap Pillar \\
\hline Fast-growing population & Not covered as such \\
\hline Climate change & $\begin{array}{l}\text { Pillar 5: } \\
\text { Environmental Sustainability }\end{array}$ \\
\hline Costly logistics & $\begin{array}{l}\text { Pillar 3: } \\
\text { Sector Policy }\end{array}$ \\
\hline High cost of inputs & $\begin{array}{l}\text { Pillar 3: } \\
\text { Sector Policy }\end{array}$ \\
\hline Unresolved land issues & Not covered as such \\
\hline Ageing tea bushes & $\begin{array}{l}\text { Pillars 1 and 4: } \\
\text { Profitable } \\
\text { Estates/Profitable Smallholder } \\
\text { Sectors }\end{array}$ \\
\hline Unsustainable low wages & $\begin{array}{l}\text { Pillar 3: } \\
\text { Living Wage }\end{array}$ \\
\hline Difficult access to finance, both for estates and & $\begin{array}{l}\text { Pillars 1 and 4: } \\
\text { Profitable } \\
\text { Estates/Profitable Smallholder } \\
\text { Sectors }\end{array}$ \\
\hline decision-making processes & $\begin{array}{l}\text { Pillar 4: } \\
\text { Profitable Smallholder Sector }\end{array}$ \\
\hline
\end{tabular}

Regarding the topic of population growth, this may not require a new/additional pillar, but the implications should be analysed more thoroughly and the potential negative impacts considered for the existing pillars on environment, smallholders and estates in order to design mitigation measures and/or re-design existing sub-projects. This might imply reaching out to new partners/allies (government/non-government) who specialize in population growth activities and are already present in Mulanje and Thyolo districts.

As outlined in chapter 3.1, it seems that the problem of 'unresolved land issues' does create considerable social tension between stakeholders, and needs to be addressed in a collaborative way to find solutions that are acceptable to everyone. One way to address this could be to consider a subproject 'woven' into Pillars 4 (Smallholders) and 3 (Sector Policy).

A further exercise on alignment with the Roadmap was undertaken during the Mulanje workshop, when during Step 3: 'Proposals for Way Forward', the participants prioritized five actions for further analysis, to tackle the risks of climate change, low wages/harassment, ageing tea bushes and logistics/infrastructure. Given the nature of the process, this prioritization does not necessarily take into account strategic considerations and viewpoints. On the other hand, many risks and their potential solutions emphasized during discussions do make a strong case for a shift to more systemic thinking, highlighting the interconnectivity of issues across several risks and threats identified. 


\section{Priority action 1}

A first prioritized action is around the environmental issue of conservation by smallholders and estates looking at the wider catchment area, i.e. not exclusively focused on tea gardens/estates only. To a certain degree this is captured in Pillar 5: Re-/afforestation/Environmental Management Plan, and a Working Group led by ETP already exists to address this workstream. However, it is not clear if current Malawi2020 workplans expand their scope sufficiently to a catchment area approach, or rather are limited to environmental management of tea gardens/plantations only. The programme would benefit from such an extension as the environmental risks identified very often have their root causes in the wider catchment area, and are not under direct control of tea estates and smallholders. This would of course require that new and different stakeholders are approached and invited to participate, especially government agencies, both local and regional, and community organizations whether within or outside the scope of Malawi2020. Again, the existing Working Group should discuss this and take appropriate decisions.

\section{Priority action 2}

The second action involves the introduction of energy-efficient stoves. For smallholder households this is covered currently under Pillar 5 . The workshop clearly identified a link between this workstream and two other risks identified, one around yield/quality of tea gardens, and also to deforestation and the need for firewood due to lack of alternative energy sources for households. As this firewood shortage has led to the increased collection of organic material from pruned tea bushes on the estates to use as fuel, there is a direct negative impact in terms of soil and biodiversity depletion, affecting both yield and quality of tea. The existing Alternative Energy Working Group led by TAML could look further into these interconnections. The VRA discussions, it is worth noting, highlighted that in order for energy-saving stoves to achieve their desired outcomes it is crucial to ensure that they are widely adopted by the population. Many similar schemes in Africa have failed precisely because of insufficient uptake. There is a clear commitment of VRA participants to work together to maximize adoption of the new stoves.

\section{Priority action 3}

The third prioritized action concerns alternative generation of own energy by estates. The Roadmap currently covers this under Pillar 5: Sustainable Energy - Exploring Alternative Sources, and the Alternative Energy Working Group is led by TAML in cooperation with ETP. As a first step and baseline for further action, the group suggested carrying out energy audits on all factories. This activity is pending in the current action plan of Malawi2020, and will be carried out by the factories themselves. The way forward on this workstream needs to be discussed thoroughly, as it is of course intimately linked to other issues raised during VRA, such as conservation at a catchment-area level and climate change.

\section{Priority action 4}

As a fourth selected action, the group identified the need for the living wage pursued by Malawi2020 to be embedded within the country's legal and political frameworks in order to ensure its application and sustainability. Engaging with all key stakeholders, not just a selective group of them, around an open and transparent social dialogue was seen as crucial to achieving this objective. Opening up this discussion to other important commodities in due course (e.g. to the domestic cotton and tobacco industries) could also benefit the sustainability of the living wage and prevent inter-industry disputes. The Roadmap does have, under Pillar 3, a component of Sector Policy, but no Working Group has been established for this. This could be considered as an action point, and its potential leads are TAML and the Plantations Agriculture Workers Union of Malawi (PAWUM) together with IDH, GIZ and Oxfam. 


\section{Priority action 5}

Finally, the Knowledge Group acknowledged as a fifth priority action the need for replanting tea bushes, both for estates and smallholders (however, many international tea buyers actually consider quality improvement of existing capacity more important than further expanding production/yield). Replanting is already considered in the Roadmap under Pillars 1 and 4 for improving profitability of the estates and smallholder sectors. Respective working groups are led by TAML for the estate sector and ETP for smallholders. Both groups could benefit from inputs provided at the workshop to better inform decisions on replanting - especially on best clones in relation not only to boosting yield but also quality and, crucially, on mitigation measures to reduce climate change impacts regarding higher pest incidence and unpredictable rainfall patterns/prolonged drought. Additionally, the group mentioned the importance of clone plant material selection that is appropriate for further mechanization, while recognizing that this could threaten employment levels of unskilled women labourers, one of the most vulnerable social groups identified in the VRA process.

While these identified priority actions do align with current Roadmap pillars and activities, it would be advisable to analyse the details of the workgroup discussions and the inputs provided in order to review the current workplans. Do they mitigate the impacts on the most vulnerable groups? Do they provide a cross-cutting approach looking into other pillars and their activities? Are all the potential allies/partners already on board, or could additional ones be brought in? Even if all the activities are aligned as such, are any changes necessary regarding methodology/how to go about them? 


\section{OUTCOMES}

This section explores the implications of the VRA exercise for Malawi2020, the Oxfam in Malawi team, and the Oxfam team working on resilience and climate change based in the UK headquarters.

\subsection{ISSUES DIRECTLY RELATED TO MALAWI2020}

The VRA process confirms and validates in most parts the existing Roadmap designed during the Malawi2020 planning process in 2015. This reflects the enormity of the challenges the Malawi tea industry is facing across commercial, social and environmental issues. Of course, different stakeholders put their emphasis and importance on different parts of the analysis. However, the process overall has clearly highlighted the interconnectivity of the various risks identified. It is important that the Programme Coordination looks at the existing workplan to make sure that there is strong complementary connection across pillars regarding cross-sectorial risks such as climate change, population growth and unresolved land issues. It will be important for the Malawi2020 Steering Committee to consciously and strategically decide how to energize and strengthen the advocacy work needed in order to tackle the broader, systemic issues identified during the VRA. There is a strong case that influencing government, CSOs and the donor community around these topics will be crucial to achieving the overall objectives of the Malawi2020 programme.

\section{'Other sectors open up to dialogue. Tea has not. It needs to do that in order for government to get more involved. Malawi2020 is a way to make that happen.'}

\section{- Knowledge Group}

These macro- or landscape-level issues - what to do about transport/logistics, climate change/environmental conservation work in catchment areas, sector minimum-wage setting based on living wage, and unresolved land issues - do not seem fully covered by the Roadmap. To work on these would need decisive government intervention and participation. It might be important to include an advocacy initiative led by TAML and PAWUM to get the traction needed from government, donors and civil society organizations, and hence boost the Pillar 3: Sector Policy workstream, which so far looks quite generic and without major outputs.

The findings of the prioritized risks/threats and detailed proposal of actions will be shared with the existing Malawi2020 Working Groups to enrich their understanding of the issues and incorporate any suggestions into their future workplans, especially for 2017.

Each responsible/accountable Steering Committee organization should review existing workplans to see if there is adequate consideration to address different levels of vulnerability of different social groups (Figure 1) and take appropriate actions.

Above all, a most valuable outcome of the process has been a much better understanding among stakeholders of each other's concerns, risks and issues. It also created an enabling environment for local stakeholders to work together and seek shared solutions to the issues raised. This is an important step forward to ensure that, despite differences in opinion and interests, we find common 
ground to achieve the overall aim of Malawi2020. It is critical that Malawi2020 continues as a multistakeholder engagement process/strategy which meaningfully includes so-called vulnerable or marginalized groups. Their voices must continue to be heard in shaping proposals for ways forward on the issues that - as the VRA process has made further evident - directly affect them within the tea industry. Hence, strengthening the participation of these groups in Malawi2020 decision-making processes, from existing Working Groups upwards, is vital to ensure that the benefits of all the activities and initiatives actually reach the most vulnerable.

\section{'At the beginning of the workshop, each one was pushing their own agenda, but now we see that challenges are quite common.'}

\section{- Knowledge Group member}

Furthermore, there was willingness of all participants at the VRA workshop to explore the possibility that this Malawi-based multi-stakeholder forum could continue to function as a 'sounding board' to the Evaluation Committee of Malawi2020, to provide a local perspective and to feed back on the progress and achievements of the programme over the coming years. How to set this up and implement it should be further explored by the Evaluation Committee, specifically its Chair.

\subsection{ISSUES RELATING TO THE WORK OF OXFAM IN MALAWI}

The VRA relates to and will strengthen and inform Oxfam in Malawi's work in the following ways:

1. It helped Oxfam in Malawi to understand the vulnerability of different social groups related to the tea sector, and to understand the impacts of the hazards on these groups. This will enable us to focus on the issues that have been raised - for example on harassment, logistical problems, climate change etc. - when implementing our work on tea wages.

2. It helped to unearth opportunities for making links with Oxfam's ongoing influencing work. For example, the findings of the VRA have helped to produce evidence which will be used to influence implementation of the recently approved climate change policy, and for climate financing and adaptation mechanisms. Oxfam's advocacy work around climate financing/implementation of policies will benefit both the smallholders and large tea estates in the long run.

3. The VRA provided evidence to back up our influencing work on governance/active citizenship; e.g. where government is being called on to be accountable and transparent in managing public funds raised from taxes (tax justice), the VRA work will provide evidence to push the government to deliver basic needs to people (water, health, schools, roads infrastructure etc.), thereby reducing the burden on tea estates to provide these services to the surrounding communities.

4. The outcome of Malawi2020 to improve livelihoods through improved wages will benefit both smallholder tea farmers and the estate workers, since they will earn better wages as a result of this programme. Improved livelihoods is one of the aims of Oxfam's current strategy.

5. Improving the tea industry and profitability of the sector will result in increased revenues for both tea estates and smallholders, and will also benefit surrounding communities and the local economy. The contribution of the tea sector to Malawi's economy will also increase. 


\subsection{ISSUES RELATING TO OXFAM'S ECONOMIC JUSTICE TEAM AND THE RESILIENCE KNOWLEDGE HUB}

This VRA has shown that it is possible to effectively bring together different stakeholders for concerted planning and action in Malawi. The learning and experience from this could be developed and applied further to look at one or more cross-sectoral issues identified by the VRA, such as the need for integrated catchment planning, or irrigation, or better weather forecasting to address climate change impacts. Such an approach would help address some critical areas, enable Oxfam in Malawi to be a convener and broker of change processes achieving impact at the wider 'landscape' scale, and build capacity for cross-sectoral planning around difficult issues within Malawi. This approach would require ongoing collaboration between Oxfam in Malawi and Oxfam GB's water, work and private sector teams.

Within the scope of the tea industry, it would be interesting to explore the role that the private sector can and does play in resilience building, and what actions Oxfam can take to leverage the private sector to enhance the resilience of poor and vulnerable people. DFID is increasingly interested in 'leveraging the private sector' to deliver climate resilience; however, it is not clear how realistic such an ambition is. The work in Malawi offers a very practical example that could be developed and at least shared with DFID. 


\section{APPENDIX 1: GLOSSARY OF ACRONYMS}

\begin{tabular}{|l|l|}
\hline ACCRA & Africa Climate Change Resilience Alliance \\
\hline CBA & Collective bargaining agreement \\
\hline CSO & Civil society organization \\
\hline DFID & UK's Department for International Development \\
\hline EAD & Environmental Affairs Department, Malawi \\
\hline ETP & Ethical Tea Partnership \\
\hline GIZ & German Organization for International Cooperation \\
\hline HH & Household \\
\hline IDH & Sustainable Trade Initiative \\
\hline MERA & Malawi Energy Regulatory Authority \\
\hline MRTDC & Malawi Industrial Research and Technology Development Centre \\
\hline MUST & Malawi University of Science and Technology \\
\hline NGO & Non-governmental organization \\
\hline PAWUM & Plantations Agriculture Workers Union of Malawi \\
\hline PWD & Persons with disabilities \\
\hline SHTG & Smallholder (small scale) tea growers \\
\hline TAML & Tea Association of Malawi \\
\hline UTZ & A certification company promoting sustainable farming \\
\hline VRA & Vulnerability and Risk Assessment \\
\hline
\end{tabular}




\section{APPENDIX 2: ORIGINAL LIST OF HAZARDS AND ISSUES}

The list of hazards and issues was compiled ahead of the VRA, during a workshop conducted in Mulanje in June 2016, through consultation with a broad range of stakeholders relevant to the Malawian tea industry: from local-level stakeholders such as community representatives, SHTG, local government, to representatives from tea estates, district and national government, private sector at national and international levels, donors and NGOs. The original list included more than 40 hazards and issues, and was narrowed down to the 29 included in the list below by merging and renaming similar categories.

The list of 29 hazards and issues was presented to the Knowledge Group at the beginning of the VRA workshop. The Knowledge Group voted which hazards and issues it considered to be the most relevant, and a discussion ensued. The result was the final selection of 17 hazards and issues that were included in step 1 of the process: the 'Initial Vulnerability Assessment' - and listed in Table 1. 
Table 1: 17 hazards and issues included in step one of the initial VRA

\begin{tabular}{|c|c|}
\hline & Hazards and issues \\
\hline 1 & Insufficient and underutilized irrigation systems for tea and other crops \\
\hline 2 & $\begin{array}{l}\text { Climate change: Changing and uncertain weather patterns (especially rain)/drought/high } \\
\text { temperatures and heatwaves/floods }\end{array}$ \\
\hline 3 & $\begin{array}{l}\text { Steep price fluctuation/global oversupply - including Kenya's overproduction and Tanzania } \\
\text { and Uganda's replanting programmes/domestic institutions lack of influence in global market }\end{array}$ \\
\hline 4 & Unsustainable (low) wages: food insecurity, poverty \\
\hline 5 & Unsustainable (high) wages: loss of competitiveness \\
\hline 6 & Inconsistent adoption of improved labour conditions by producers \\
\hline 7 & Increased mechanization of tea plucking: unemployment \\
\hline 8 & $\begin{array}{l}\text { Insufficient investment in extension services and technology/techniques; underinvestment in } \\
\text { research and development }\end{array}$ \\
\hline 9 & High costs of inputs (other than labour) \\
\hline 10 & $\begin{array}{l}\text { Local-level impact: increased trends of deforestation/soil depletion and erosion/further } \\
\text { encroachment onto Mount Mulanje }\end{array}$ \\
\hline 11 & Poor representation of SHTG in decision-making processes/low worker representation \\
\hline 12 & Lack of alternatives to agriculture-based livelihoods/difficult access to markets for SHTG \\
\hline 13 & $\begin{array}{l}\text { Limited access to and uptake of information (meteorological data, market prices, etc.) and } \\
\text { climate change knowledge }\end{array}$ \\
\hline 14 & Insufficient consideration of gender in policies that apply to the tea industry \\
\hline 15 & Ageing tea bushes/high cost of replanting \\
\hline 16 & Difficult access to finance \\
\hline 17 & Pests and diseases \\
\hline 18 & Macro-economic and political instability domestically and internationally \\
\hline 19 & Fast-growing population: food insecurity, malnutrition, poor health, conflict over land \\
\hline 20 & $\begin{array}{l}\text { Unattractive employment conditions: difficulty in hiring workers at start of season, young } \\
\text { people not engaged }\end{array}$ \\
\hline 21 & Unresolved land issues \\
\hline 22 & Costly logistics and poor infrastructure \\
\hline 23 & $\begin{array}{l}\text { Difficult access by SHTG to health services and schools; estates seen as providers of basic } \\
\text { services and welfare needs }\end{array}$ \\
\hline 24 & $\begin{array}{l}\text { Harsh treatment by capitaos (including sexual harassment/exploitation) and inadequate } \\
\text { channels to raise issues/social pressures to keep issue silent }\end{array}$ \\
\hline 25 & Low commitment of buyers and retailers to Malawi2020 process \\
\hline 26 & Changes in tax policies \\
\hline 27 & Low basic and business skills of SHTG \\
\hline 28 & Insufficient energy sources/over-extraction of and dependence on firewood \\
\hline 29 & Short duration of programme vis-à-vis high expectations \\
\hline
\end{tabular}




\section{APPENDIX 3: LIST OF KNOWLEDGE GROUP MEMBERS AND FACILITATORS}

\begin{tabular}{|c|c|c|}
\hline & Name & Organization \\
\hline 1 & Sangwani Hara & TAML \\
\hline 2 & Clement Thindwa & TAML \\
\hline 3 & John Kanyuka & TAML \\
\hline 4 & Mick Van Hassel & TAML \\
\hline 5 & Grant Bramsen & TAML \\
\hline 6 & Linda Mtegha & Ministry of Labour \\
\hline 7 & Martin Kausi & Ministry of Agriculture \\
\hline 8 & Edward Thole & $\begin{array}{l}\text { CICOD - Circle for Integrated Community } \\
\text { Development }\end{array}$ \\
\hline 9 & Aubrey Kambewa & CICOD Mulanje/Thyolo \\
\hline 10 & Alfred Patel & CADECOM - Catholic Development Commission \\
\hline 11 & Greshian Khembo & PAWUM \\
\hline 12 & Dennis Banda & PAWUM \\
\hline 13 & Joyce Kaposa & Community member \\
\hline 14 & Catherine Nakiriya & Community member \\
\hline 15 & Akonda John & Community member \\
\hline 16 & Tibeth Sandikonda & Community member \\
\hline 17 & Rose Yofati & Community member \\
\hline 18 & Keson Goodson & Community member \\
\hline 19 & Edson Mvosoh & Community member \\
\hline 20 & Esther Mzembe & Agriculture - District \\
\hline 21 & Charles Katembo & District Labour Office \\
\hline 22 & William Sichinga & Tea and Coffee Merchants Association \\
\hline 23 & Maganga Maganga & Van Rees \\
\hline 24 & Frank Kandu & Translator MBC \\
\hline 25 & Dottie Makhasu & International Union of Food workers \\
\hline 26 & Wilson Maduka & District Social Welfare Office \\
\hline 27 & Mike Binali & Mulanje Police \\
\hline 28 & Thomson Kajombo & District Health Office \\
\hline 29 & John Makina & Oxfam \\
\hline 30 & Wolfgang Weinmann & Oxfam (*facilitator) \\
\hline 31 & Helen Jeans & Oxfam ("facilitator) \\
\hline 32 & Hyton Lefu & Oxfam ( ${ }^{\star}$ facilitator) \\
\hline 33 & Chimwemwe Kachepa & Oxfam ( ${ }^{\star}$ facilitator) \\
\hline 34 & Daniel Morchain & Oxfam ("facilitator) \\
\hline
\end{tabular}




\section{NOTES}

${ }^{1}$ Sigrid Nagoda (2015). New discourses but same old development approaches? Climate change adaptation policies, chronic food insecurity and development interventions in northwestern Nepal. Global Environmental Change 35; 570-579. http://dx.doi.org/10.1016/j.gloenvcha.2015.08.014

${ }^{2}$ http://policy-practice.oxfam.org.uk/publications/finding-ways-together-to-build-resilience-the-vulnerability-andrisk-assessment-593491

${ }^{3}$ See Appendix 3 for a list of the Knowledge Group members.

${ }^{4}$ C. Molefe and H Masundire (April 2016). Climate Change Vulnerability and Risk Analysis in The Bobirwa Subdistrict, Botswana: Towards Improving Livelihood Adaptation to Climate - Short Report. ASSAR website. Available at:

http://www.assar.uct.ac.za/sites/default/files/image_tool/images/138/Botswana/VRA\%20in\%20Bobirwa\%20short\%20report\%20-\%20April\%20edit.pdf and

D. Morchain (14 Jan 2016). What we've learned about vulnerability assessments and how to do them. Blogpost. Oxfam. Available at: http://policy-practice.oxfam.org.uk/blog/2016/01/what-weve-learned-aboutvulnerability-assessments

${ }^{5} \mathrm{http}: / /$ policy-practice.oxfam.org.uk/publications/understanding-wage-issues-in-the-tea-industry-287930

${ }^{6}$ Capitao is the Portuguese word for 'foreman', i.e. the overseer of labourers at the tea plantation. It is used in Malawi due to its proximity to Portuguese-speaking Mozambique.

${ }^{7}$ A social group refers to a more or less homogeneous group of people within the landscape, such as 'unskilled men labourers', 'children' or 'estates'. The reason for categorizing people into social groups is to ensure that all relevant groups are included in the analysis - and that marginalized groups of people are not left out - as a viable and sufficiently robust alternative to individual or household-level assessments that are time- and resource-intensive.

${ }^{8}$ The Knowledge Group refers to the participants of the VRA, who jointly developed the thinking and analysis during the two-day workshop. The list of Knowledge Group members is included in the Appendices.

${ }^{9}$ This statement should not be misunderstood to mean that SHTG are less vulnerable to climate change than estates. The adaptive capacity of estates is higher than that of SHTG (e.g. easier access to credit, agricultural inputs, external support, savings). Adaptive capacity is explored in step 3 of the VRA.

${ }^{10}$ A collective agreement is a written contract between the employer and a union that outlines many of the terms and conditions of employment for employees in a bargaining unit. The terms and conditions are reached through collective bargaining between the employer and the union.

${ }^{11}$ For reference, the four risks (or 'hazards and issues') that were pursued by the Knowledge Group during the VRA were, as discussed throughout the report: climate change, low wages and harassment, ageing tea bushes, and logistics and infrastructure. 


\section{Research reports}

This research report was written to share research results, to contribute to public debate and to invite feedback on development and humanitarian policy and practice. It does not necessarily reflect the policy positions of the publishing organizations. The views expressed are those of the author and not necessarily those of the publishers.

For more information, or to comment on this report, email Wolfgang Weinmann, Ethical Trade Adviser, Oxfam GB at wweinmann1@oxfam.org.uk

(๖) Oxfam International October 2016

This publication is copyright but the text may be used free of charge for the purposes of advocacy, campaigning, education, and research, provided that the source is acknowledged in full. The copyright holder requests that all such use be registered with them for impact assessment purposes. For copying in any other circumstances, or for re-use in other publications, or for translation or adaptation, permission must be secured and a fee may be charged. Email policyandpractice@oxfam.org.uk.

The information in this publication is correct at the time of going to press.

Published by Oxfam GB for Oxfam International under ISBN 978-0-85598-796-1 in October 2016.

Oxfam GB, Oxfam House, John Smith Drive, Cowley, Oxford, OX4 2JY, UK.

\section{OXFAM}

Oxfam is an international confederation of 20 organizations networked together in more than 90 countries, as part of a global movement for change, to build a future free from the injustice of poverty. Please write to any of the agencies for further information, or visit www.oxfam.org. 